\title{
Allelopathic Action of the Níger (Guizotia abyssinica Cass.) on Soybean (Glycine max (L.) Merrill)
}

\author{
Gustavo Negro Devequi \\ Department of Agronomy, University Center of Maringá - UNICESUMAR \\ Avenue Guedner, n 1610, Jardim Aclimação, CEP: 87050-390, Maringá, Paraná, Brazil \\ Tel: +55-44-99986-0922Ｅ-mail: gustavodevequi@msn.com
}

\begin{abstract}
Mateus Luiz de Oliveira Freitas
Department of Agronomy, University Center of Maringá - UNICESUMAR Avenue Guedner, n 1610, Jardim Aclimação, CEP: 87050-390, Maringá, Paraná, Brazil Tel: +55-44-99868-9494_E-mail: mateusluiz_freitas@hotmail.com
\end{abstract}

Flávia Helena de Moura Libório

Master Program in Science, Technology and Food Safety, University Center of Maringá - UNICESUMAR

Avenue Guedner, n 1610, Jardim Aclimação, CEP: 87050-390, Maringá, Paraná, Brazil Tel: +55-44-98816-2232Ｅ-mail: flaviahfmoura@gmail.com

\begin{abstract}
Luciano Ivano da Silva
Department of Agronomy, State Universit of Maringá - UEM

Avenue Colombo, 5790, Jardim Universitário, CEP 87020-900 - Maringá, Paraná, Brazil

Tel: +55-44-99902-9650Ｅ-mail: lucianobiopr@yahoo.com.br
\end{abstract}

Patrícia da Costa Zonetti

Department of Agronomic Sciences, Federal University of Paraná - UFPR

Street Pioneiro, 2153, CEP: 85950-000, Palotina, Paraná, Brazil

Tel: +55-44-99951-6005Ｅ-mail: patricia.zonetti@gmail.com 


\section{Daniele Fernanda Felipe}

Master Program in Science, Technology and Food Safety, University Center of Maringá - UNICESUMAR

Avenue Guedner, nº 1610, Jardim Aclimação, CEP: 87050-390, Maringá, Paraná, Brazil Tel: +55-44-99953-5123Ｅ-mail: daniele.felipe@uol.com.br

\section{Anny Rosi Mannigel}

Master Program in Science, Technology and Food Safety, University Center of Maringá - UNICESUMAR

Avenue Guedner, nº 1610, Jardim Aclimação, CEP: 87050-390, Maringá, Paraná, Brazil Tel: +55-44-99116-9085Ｅ-mail: armannigel@gmail.com

André Ribeiro da Costa

Master Program in Science, Technology and Food Safety, University Center of Maringá - UNICESUMAR

Avenue Guedner, n 1610, Jardim Aclimação, CEP: 87050-390, Maringá, Paraná, Brazil Tel: +55-44-99801-2700Ｅ-mail: rcosta4@ hotmail.com

\section{Ricardo Andreola}

Master Program in Science, Technology and Food Safety, University Center of Maringá - UNICESUMAR

Avenue Guedner, n 1610, Jardim Aclimação, CEP: 87050-390, Maringá, Paraná, Brazil Tel: +55-44-99129-9964Ｅ-mail: randreola25@uol.com.br

Aline Maria Orbolato Gonçalves-Zuliani

Department of Agronomy, University Center of Maringá - UNICESUMAR Avenue Guedner, nº 1610, Jardim Aclimação, CEP: 87050-390, Maringá, Paraná, Brazil Tel: +55-44-99918-4124Ｅ-mail: alineorb@hotmail.com 
Edison Schmidt Filho

Master Program in Clean Technologies, University Center of Maringá - UNICESUMAR Avenue Guedner, nº 1610, Jardim Aclimação, CEP: 87050-390, Maringá, Paraná, Brazil Tel: +55-41-99677-7212Ｅ-mail: schmidtufpr@yahoo.com

Graciene de Souza Bido (Corresponding author)

Master Program in Science, Technology and Food Safety, University Center of Maringá - UNICESUMAR

Avenue Guedner, nº 1610, Jardim Aclimação, CEP: 87050-390, Maringá, Paraná, Brazil Tel: +55-44-99916-1664Ｅ-mail: gsbido@hotmail.com

Received: Sep. 6, 2019

doi:10.5296/jas.v8i1.15401
Accepted: Oct. 7, 2019

Published: Oct. 11, 2019

URL: https://doi.org/10.5296/jas.v8i1.15401

\begin{abstract}
Soybean (Glycine max (L.) Merrill) is an agricultural crop with a large increase in production in the last three decades and is an essential component in the manufacture of animal and human food. Understanding the interactions between crop and other plant species used as green manure that can improve yield and so reduce environmental damage. Forages can release secondary metabolites in the environment that influence in a beneficial or harmful way to other plants, characterizing the allelopathy process. The Níger (Guizotia abyssinica Cass.) is used in agricultural systems because it releases allelochemicals, especially flavonoids. Therefore, this study is aimed to evaluate the allelopathic effects of the Niger straw on the germination and initial growth of soybean seedlings. The treatments consisted of aqueous extracts of niger stems, leaves and roots in different concentrations $(0 ; 25 ; 50 ; 75$ and $100 \%$ ). For each treatment, five replications were performed, each composed by a 25 seeds distributed in gearbox kept in incubator chamber for 7 days at $25^{\circ} \mathrm{C}$ and 12 hours photo period. The experimental design was completely randomized and the data were evaluated by analysis of variance and the means of treatments compared by Tukey's test at $5 \%$ significance. The results show a reduction in germination and initial growth of soybean seedlings submitted to aqueous extract of niger stem and roots. In contrast, the aqueous extract of the Niger leaves increased the length of soybean seedlings. The allelopathic effects of the Niger probably occur due to the presence of flavonoids in the tissues of this plant species.
\end{abstract}

Keywords: allelopathy, green manure, flavonoids 


\section{Introduction}

The Soybean (Glycine max (L.) Merrill.) is among the main crops consumed and produced worldwide, behind only corn, wheat and rice (Hirakuri and Lazzarotto, 2014). Among the seeds, soy is the most important source of oil and proteins (Hartman et al., 2011), is widely used by agribusiness, chemical and food industry. It is a crop with a important value in the world economy, responsible for most of the oil seed production (Wilson, 2008). The large consumption and the new genetic materials developed, to justify the widespread cultivation of soybean and enable their's consumption worldwide, especially in the United States, Brazil, Argentina and China (Campos, 2011; Nishinari et al., 2014, Rocha et al., 2018).

With the progressive increase in world soybean production it became necessary to find alternative cultivation, such as the implementation of a no-tillage system which can increase soil productivity in a sustainable and economical way by promoting improvements in physical, chemical and biological attributes, helping to protect the soil from erosion and irradiation, besides conserving moisture and providing nutrient cycling, which motivates farmers to use green manure in crop succession and rotation systems (Carvalho et al. 2014; Simonetti et al., 2019).

This planting techniques were pointed out as a system capable of contributing to sustainability by maintaining the straw of the previous crop, so the organic matter maintained can release allelochemicals that act as herbicides, reducing agrochemical costs and has an environmental impact (Darolt, 2000; Fontanétti et al., 2004; Monquero et al., 2009). Knowledge of the allelopathic effects of various substances is important to understand interactions between plant species in both natural and agricultural ecosystems (Jabran et al., 2015).

Allelopathy is defined as any, direct or indirect, beneficial or harmful, effect of a plant or microorganisms on other organisms by producing chemical compounds that are released into the environment. (IAS, 2015; Santos, 2012; Linares et al., 2006). Such substances are found distributed in varying concentrations in different parts of the plant and during its life cycle. They can be found in all tissues, including leaves, flowers, fruits, roots, rhizomes, stems and seeds (Almeida et al., 2008) and are released into the environment by volatilization, leaching and decomposition (Blum, 2011).

When these substances are in insufficient quantities, allelopathic effects may be observed on germination, growth and/or development of plants and microorganisms. (Barbosa et al., 2018; Battistus et al., 2011). Effects may be intra- and interspecific and may affect both the donor and recipient organisms (Oliveira, 2009).

The Niger (Guizotia abyssinica Cass.) is an annual herbaceous plant originally from Ethiopia. It belongs to the Asteraceae family and can reach up to $2 \mathrm{~m}$ in height, being the only cultivable species of the genus Guizotia (Getinet and Sharma, 1996; Gordin et al., 2014). The seeds contain $30 \%$ oil and are used for commercial biodiesel production (Sarin et al., 2009). Niger is also used as green manure for soil by increasing organic matter and its seeds can be used as human food (Carneiro et al., 2008; Seegeler, 1983). It is adapted to different soil 
types and grows in temperate and tropical regions (Bottega et al., 2013)

This plant is rich in flavonoids, class of secondary metabolites known for allelopathic potential (Taiz et al., 2017). Kuo et al. (2007) identified nine flavonoids isolated from the aerial parts: (-)-liquiritigenin, (-)-7,3',4'-trihydroxyflavanone, (-)-7,8,3',4'-tetrahydroxylflavanone, 7,3',4'-trihydroxyflavone, quercetin, isoliquiritigenin, butein, okanin, and 3,2',4'-trihydroxy-4,3'-dimethoxychalcone. Therefore, it is a potential donor of phytotoxins capable of acting on the natural inhibition of agricultural pests, especially on weeds (Carneiro et al, 2008). However, little is known about the allelopathic effects of the Niger, especially on agricultural crops, and there are no reports on soy studies.

The study of the allelopathic effect of straw used for mulching on cultivated species is generally done with bioassays that use aqueous or alcoholic extracts in germination chambers tests, evaluating germination percentage, root elongation and fresh and dry biomass of roots and shoot (De Carvalho, et., 2014).

Thus, this study is aimed to evaluate the effects of Guizotia abyssinica Cass. extracts on seed germination and initial root and shoot growth, as well as fresh and dried biomass of soybean seedling.

\section{Material and Methods}

\subsection{Vegetable Material}

The Niger (Guizotia abyssinica Cass.) production was conducted at the experimental farm of the University Center of Maringá - UNICESUMAR, Maringá, Paraná, Brazil, altitude of 550 meters, Eutrophic Red Latosol soil and subtropical climate.

The collection was done after 3 months and before flowering, selecting plants without physical injuries. No treatment or control of pests and diseases was performed.

The soybean variety (Glycine $\max$ (L.) Merrill.) used was BRS 216, which was provided by the Brazilian Agricultural Research Corporation - EMBRAPA/Soybean, Londrina, Paraná, Brazil.

\subsection{Obtaining Aqueous Extracts of the Niger}

Roots, stems and leaves of the Niger were separated, packed in paper bags and kept in a drying oven until constant mass, at $50^{\circ} \mathrm{C}$.

After the drying period, $3 \mathrm{~g}$ of each vegetable part was weighed and and distilled water was added in the proportion of $3 \mathrm{~g}$ of dry mass of roots, stems or leaves to $100 \mathrm{~mL}$ of the distilled water, crushed in a blender and kept at rest for 5 minutes.

Subsequently, the material was filtered and the obtained extract was considered as $100 \%$ aqueous extract for each plant part. This extract was diluted with distilled water to obtain the other concentrations $(25,50$ and $75 \%)$. The control $(0 \%)$ consisted only a distilled water.

\subsection{Experimental Conduction}




\section{Macrothink Institute ${ }^{\mathrm{TM}}$}

The soybean seeds were dipped in $2 \%$ sodium hypochlorite solution $(\mathrm{NaClO})$ for 2 minutes and washed thoroughly with distilled water.

Twenty-five soybean seeds were distributed in gerbox $(11 \times 11 \times 3,5 \mathrm{~cm})$ containing two sheets of autoclaved germination paper and $14 \mathrm{~mL}$ of the aqueous extract were added at different concentrations $(0,25,50,75$ and 100\%). After sowing, the gerboxes were conditioned in a B.O.D. germination chamber at $25^{\circ} \mathrm{C}$ with a photoperiod of 12 hours for seven days.

After the incubation period, germination and initial growth of soybean were evaluated.

\subsection{Germination}

Germinated seeds were checked on the seventh day and then the germination percentage was determined. The seeds with $2 \mathrm{~mm}$ of root protrusion were considered germinated. (Hartmann et al., 2001)

The percentage of germination (PG) was obtained by representing the percentage of seeds germinated in relation to the total number of seeds per gearbox under the determined experimental conditions (Ferreira and Borguetti, 2004), given by:

$\mathrm{PG}=\left(\sum \mathrm{ni} \cdot \mathrm{N}^{-1}\right) \cdot 100$

where: $\sum$ ni $=$ total number of germinated seeds; $\mathrm{N}^{-1}=$ number of seeds arranged to germinate.

\subsection{Initial Growth}

To analyze the initial growth of soybean seedlings, the root and shoot length and their biomass, fresh and dry, were evaluated.

Shoot length was determined between apex and root-shoot junction, while the length of the main root corresponded to the distance between this region and the root end, both measured with a millimeter ruler. Only seedlings with development capacity were measured (Brasil, 2009).

Subsequently, root and shoot fresh biomass of soybean seedlings were obtained by weighing in analytical balance. The samples were then packed in paper bags and kept in a drying oven until constant mass, at $50^{\circ} \mathrm{C}$, to obtain the value of dry biomass (Borella and Pastorini, 2009).

\subsection{Statistical Analysis}

The experimental design was completely randomized with five replications of each treatment. Data were evaluated by analysis of variance and means between treatments compared by Tukey's test at 5\% significance, using the statistical program Sisvar® (Ferreira, 2014).

\section{Results and Discussion}

After treatment with aqueous extract from the Niger stem, there were reductions in soybean germination and initial growth (Table 1). However, the germination percentage of soybean seeds was inhibited (9.5\%) only at 50\% concentration of this extract. According to Ferreira and Borghetti (2004), germination is less responsive to allelochemicals than to growth. 
Several studies indicate that soybean seed germination is poorly sensitive to the effects of allelopathic compounds. Freitas et al. (2010) reported that Pinus extracts did not influence soybean seed germination as well as Nunes et al. (2014) did not observe changes in the germination of this crop after seeds were submitted to extracts of canola (Brassica napus L.), crambe (Crambe abyssinica Hochst), sunn hemp (Crotalaria juncea L.), linseed (Linum usitatissimum L.) and forage turnip (Raphanus sativus L.). The results of Silva et al. (2015) also corroborate those obtained in this research, where extracts of Salvia officinalis L. had no effects on soybean germination.

Table 1. Seed germination and initial growth of soybean seedlings treated with aqueous extract of niger stem at different concentrations (0, 25, 50, 75 and 100\%). GP - Germination Percentage; RL - Root Length; SL - Shoot Length; FRB - Fresh Root Biomass; DRB - Dry Root Biomass; FSB - Fresh Shoot Biomass and DSB - Dry Shoot Biomass

\begin{tabular}{l|l|l|l|l|l|l|l}
\hline Treatment $(\%)$ & GP $(\%)$ & RL (cm) & SL (cm) & FRB (mg) & DRB (mg) & FSB (mg) & DSB (mg) \\
\hline $\mathbf{0}$ & $21.00 \pm 0.45 \mathrm{a}$ & $4.91 \pm 0.38 \mathrm{ab}$ & $3.24 \pm 0.34 \mathrm{a} 2.17 \pm 0.41 \mathrm{a}$ & $0.23 \pm 0.02 \mathrm{a}$ & $1.77 \pm 0.32 \mathrm{a}$ & $0.19 \pm 0.02 \mathrm{a}$ \\
\hline $\mathbf{2 5}$ & $21.60 \pm 0.68 \mathrm{a}$ & $5.80 \pm 0.40 \mathrm{a}$ & $2.11 \pm 0.17 \mathrm{~b}$ & $1.26 \pm 0.13 \mathrm{~b}$ & $0.18 \pm 0.01 \mathrm{ab}$ & $1.44 \pm 0.18 \mathrm{ab}$ & $0.22 \pm 0.01 \mathrm{a}$ \\
\hline $\mathbf{5 0}$ & $19.00 \pm 0.55 \mathrm{~b}$ & $4.39 \pm 0.27 \mathrm{~b}$ & $1.96 \pm 0.34 \mathrm{~b} 0.93 \pm 0.11 \mathrm{~b}$ & $0.15 \pm 0.01 \mathrm{~b}$ & $0.91 \pm 0.07 \mathrm{~b}$ & $0.19 \pm 0.01 \mathrm{a}$ \\
\hline $\mathbf{7 5}$ & $20.00 \pm 0.35 \mathrm{ab}$ & $5.17 \pm 0.45 \mathrm{ab}$ & $1.99 \pm 0.14 \mathrm{~b}$ & $1.22 \pm 0.21 \mathrm{~b}$ & $0.17 \pm 0.01 \mathrm{~b}$ & $1.11 \pm 0.08 \mathrm{~b}$ & $0.23 \pm 0.01 \mathrm{a}$ \\
\hline $\mathbf{1 0 0}$ & $21.20 \pm 0.22 \mathrm{a}$ & $4.20 \pm 0.06 \mathrm{~b}$ & $1.53 \pm 0.11 \mathrm{~b} 0.87 \pm 0.058 \mathrm{~b}$ & $0.15 \pm 0.01 \mathrm{~b}$ & $0.95 \pm 0.04 \mathrm{~b}$ & $0.21 \pm 0.01 \mathrm{a}$ \\
\hline
\end{tabular}

Means followed by the same letter do not differ statistically from each other by the Tukey test at $5 \%$ significance. Data are represented as mean \pm standard error of mean (SEM)

Regarding the growth of soybean seedlings, the root and shoot length decreased, mainly in the highest concentration studied (100\%), where there were decreases greater than 14 and $52 \%$, respectively.

Biomass, another growth parameter, was also decreased after treatment with aqueous extract of the Niger stem, except the dry shoot biomass of soybean seedling, which was not altered. Fresh and dry root biomass presented larger reductions, at $100 \%$ concentration, where there were decreases of approximately 60 and 35\%, respectively, when compared to the control experimente; while fresh shoot biomass was more inhibited $(48.6 \%)$ in the treatment containing $50 \%$ of the niger stem aqueous extract (Table 1).

Allelochemicals in aqueous extracts promote reductions in seedling growth by decreasing cell division and elongation (Gomes et al., 2019; Javaid and Anjum, 2006). Despite few studies investigating the allelopathic effects of the Niger, recent studies indicate phytotoxic potential of this plant, probably due to the presence of flavonoids, an important class of polyphenols with strong biological activity. 
The aqueous extract of the Niger leaves did not affect the seed germination percentage and the fresh and dry biomass of soybean root and shoot in none of the concentrations studied (Table 2).

Table 2. Seed germination and initial growth of soybean seedlings treated with aqueous extract of niger leaves in different concentrations (0, 25, 50, 75 and 100\%). GP - Germination Percentage; RL - Root Length; SL - Shoot Length; FRB - Fresh Root Biomass; DRB - Dry Root Biomass; FSB - Fresh Shoot Biomass and DSB - Dry Shoot Biomass

\begin{tabular}{l|l|l|l|l|l|l|l}
\hline $\begin{array}{l}\text { Treatment } \\
(\%)\end{array}$ & $\begin{array}{l}\text { RL } \\
(\mathbf{\%})\end{array}$ & $\begin{array}{l}\text { SL } \\
(\mathbf{c m})\end{array}$ & $\begin{array}{l}\text { FRB } \\
(\mathbf{m g})\end{array}$ & $\begin{array}{l}\text { DRB } \\
(\mathbf{m g})\end{array}$ & $\begin{array}{l}\text { FSB } \\
(\mathbf{m g})\end{array}$ & $\begin{array}{l}\text { DSB } \\
(\mathbf{m g})\end{array}$ \\
\hline $\mathbf{0}$ & $22.60 \pm 1.03 \mathrm{a}$ & $3.96 \pm 0.26 \mathrm{~b}$ & $4.00 \pm 0.22 \mathrm{~b}$ & $1.24 \pm 0.24 \mathrm{a}$ & $0.25 \pm 0.02 \mathrm{a}$ & $2.50 \pm 0.41 \mathrm{a}$ & $0.30 \pm 0.03 \mathrm{a}$ \\
\hline $\mathbf{2 5}$ & $21.20 \pm 0.80 \mathrm{a}$ & $4.93 \pm 0.42 \mathrm{ab}$ & $4.96 \pm 0.50 \mathrm{ab}$ & $1.00 \pm 0.19 \mathrm{a}$ & $0.20 \pm 0.02 \mathrm{a}$ & $2.60 \pm 0.24 \mathrm{a}$ & $0.28 \pm 0.02 \mathrm{a}$ \\
\hline $\mathbf{5 0}$ & $21.20 \pm 1.20 \mathrm{a}$ & $5.66 \pm 0.48 \mathrm{a}$ & $5.56 \pm 0.39 \mathrm{a}$ & $1.11 \pm 0.09 \mathrm{a} 0.21 \pm 0.01 \mathrm{a} 2.65 \pm 0.26 \mathrm{a}$ & $0.29 \pm 0.02 \mathrm{a}$ \\
\hline $\mathbf{7 5}$ & $22.60 \pm 0.76 \mathrm{a}$ & $5.77 \pm 0.42 \mathrm{a}$ & $5.48 \pm 0.26 \mathrm{a}$ & $1.22 \pm 0.09 \mathrm{a} 0.25 \pm 0.02 \mathrm{a} 2.70 \pm 0.19 \mathrm{a} 0.30 \pm 0.02 \mathrm{a}$ \\
\hline $\mathbf{1 0 0}$ & $20.00 \pm 0.79 \mathrm{a} 5.33 \pm 0.10 \mathrm{a}$ & $4.00 \pm 0.28 \mathrm{~b}$ & $1.25 \pm 0.21 \mathrm{a}$ & $0.26 \pm 0.02 \mathrm{a}$ & $1.71 \pm 0.26 \mathrm{a}$ & $0.24 \pm 0.01 \mathrm{a}$ \\
\hline
\end{tabular}

Means followed by the same letter do not differ statistically from each other by the Tukey test at $5 \%$ significance. Data are represented as mean \pm standard error of mean (SEM)

However, the increases in root and shoot lengths of soybean seedlings treated with aqueous extract of the Niger leaves were identified (Table 2), reaching increases of $46 \%$ for root length to $75 \%$ of the extract and increments of $39 \%$ and $37 \%$ for shoot length in treatments with 50 and $75 \%$ extract, respectively.

Allelopathic interaction depends on plant's part and extract concentration, as well as allelochemical stability and sensitivity among target species. This can be noted when comparing the results of the present study with those obtained by other researches that also evaluated the allelopathic effects of the Niger leaves. So, Gomes et al. (2017) verified inhibition of germination and root length of Ipomoea grandifolia (Dammer) O'Donell (morning glory) seedlings treated with ethanolic extract from the Niger leaves. In another study with the ethanolic extract from the Niger leaves, Gomes et al. (2019) observed germination and root length inhibition of ryegrass, as well as reduction of bittergrass germination; however, they observed increased root length of bittergrass.

The aqueous extract of niger roots, like leaves extract, did not cause changes in seed germination percentage. In contrast, seedling growth decreased significantly (Table 3). Inhibitions of up to $64.3 \%$ in root length of soybean seedlings at $50 \%$ of extract and up to $53.4 \%$ in shoot length at $100 \%$ of aqueous extract of the Niger roots were noted. 
Table 3. Seed germination and initial growth of soybean seedlings treated with aqueous extract of niger roots at different concentrations $(0,25,50,75$ and 100\%). GP - Germination Percentage; RL - Root Length; SL - Shoot Length; FRB - Fresh Root Biomass; DRB - Dry Root Biomass; FSB - Fresh Shoot Biomass and DSB - Dry Shoot Biomass

\begin{tabular}{|c|c|c|c|c|c|c|c|}
\hline \multicolumn{2}{|c|}{ TreatmentGP } & $\begin{array}{l}\mathbf{R L} \\
(\mathbf{c m})\end{array}$ & $\begin{array}{l}\text { SL } \\
(\mathbf{c m})\end{array}$ & $\begin{array}{l}\text { FRB } \\
(\mathrm{mg})\end{array}$ & $\begin{array}{l}\text { DRB } \\
(\mathbf{m g})\end{array}$ & $\begin{array}{l}\text { FSB } \\
\text { (mg) }\end{array}$ & $\begin{array}{l}\text { DSB } \\
(\mathbf{m g})\end{array}$ \\
\hline $\mathbf{0}$ & $21.00 \pm 0.32 \mathrm{a}$ & $\mathrm{a} 9.02 \pm 0.75 \mathrm{a}$ & $\mathrm{a} 5.72 \pm 0.30 \mathrm{a}$ & $\mathrm{a} 2.82 \pm 0.26 \mathrm{a}$ & $0.22 \pm 0.01$ & $3.52 \pm 0.258$ & $\mathrm{a} 0.31 \pm 0.01 \mathrm{a}$ \\
\hline 25 & $20.60 \pm 0.40 a$ & $\mathrm{a} 3.42 \pm 0.35 \mathrm{~b}$ & $b 3.56 \pm 0.14 b$ & $b \mid 1.69 \pm 0.09 b$ & $0.17 \pm 0.01 \mathrm{~b}$ & $b 2.35 \pm 0.139 \mathrm{~b}$ & $\mathrm{~b} 0.25 \pm 0.01 \mathrm{~b}$ \\
\hline 50 & $18.40 \pm 0.58 \mathrm{a}$ & $3.27 \pm 0.54 \mathrm{~b}$ & $\mathrm{~b} 3.37 \pm 0.36 \mathrm{~b}$ & $b 1.85 \pm 0.14 b$ & $0.18 \pm 0.01 \mathrm{a}$ & $2.16 \pm 0.15 b$ & $0.23 \pm 0.01 \mathrm{~b}$ \\
\hline 75 & $19.60 \pm 0.57 \mathrm{a}$ & $\mathrm{a} 3.47 \pm 0.24 \mathrm{~b}$ & $b 3.42 \pm 0.20 b$ & $b \mid 1.68 \pm 0.06 b$ & $0.19 \pm 0.01$ & $1.90 \pm 0.19 b$ & $0.23 \pm 0.01 \mathrm{~b}$ \\
\hline 100 & $19.00 \pm 0.61 \mathrm{a}$ & $\mathrm{a} 4.71 \pm 0.45 \mathrm{~b}$ & $b 2.66 \pm 0.18 b$ & $\mathrm{~b} 1.76 \pm 0.10 \mathrm{~b}$ & $0.20 \pm 0.01 \mathrm{a}$ & $1.50 \pm 0.06 \mathrm{c}$ & $0.194 \pm 0.00 \mathrm{~b}$ \\
\hline
\end{tabular}

Means followed by the same letter do not differ statistically from each other by the Tukey test at $5 \%$ significance. Data are represented as mean \pm standard error of mean (SEM)

The fresh root biomass, as well as fresh and dry shoots biomass of soybean seedling reduced significantly at all concentrations tested. A more significant reduction (57.4\%) was observed in fresh shoot biomass with $100 \%$ aqueous extract of the Niger roots. Regarding dry root biomass, a significant reduction (22.7\%) was observed only in treatments with $25 \%$ aqueous extract (Table 3).

A large number of abnormal seedlings with atrophied and necrotic primary roots were also observed when submitted to the aqueous extract of the Niger roots at the highest concentration analyzed (100\%). In general, the roots are more sensitive to the substances present in the extracts when compared to the other seedling organs (Chon et al., 2000). This is due to the fact that the roots are in direct and prolonged contact with the allelochemicals present in the extract.

Gomes et al. (2017) also verified the phytotoxic effect of the Niger on morning glory (Ipomoea grandifolia (Dammer) O'Donell) and the authors suggested that the observed effects are related to the presence and activity of flavonoids, being the Niger a potential donor of these phytotoxins. According to Paszkowski and Kremer (1988), flavones, flavonoids and isoflavonoids inhibit germination and root growth of various angiosperm species.

Flavonoids may act to control plant hormones, such as allelopathic agents and enzyme inhibitors (Formagio et al., 2010) and may induce the production of reactive oxygen species and lead to loss of cell membrane selectivity (Tur et al. 2012). In addition, the effects of these compounds on plants include decreased oxygen uptake in mitochondria and, in chloroplasts, reduced electron transport and photosystem II efficiency (Moreland and NOVITZKY, 1988). 
Few studies involving the identification of allelochemicals in the Niger are found. More research is needed on compounds in the Niger and their's mechanism of action.

\section{Final Considerations}

Although the aqueous extract of the Niger leaves increased the length of soybean seedlings, the aqueous extracts of the Niger roots and stem showed negative interference on soybean germination and initial growth. The phytotoxicity was more evident when the extract was used from roots of the Niger. Such effects possibly occurred due to the presence of flavonoids, promoting soybean susceptibility. Thus, the results suggest that the Niger should not be used in succession / rotation systems with soybean crop, however, further field studies are needed to confirm the data obtained in this research.

\section{References}

Almeida, G. D., Zucoloto, M., Zetun, M. C., Coelho, I., \& Sobreir, F. M. (2008). Estresse oxidativo em Células vegetais mediante aleloquímicos. Revista Facultad Nacional de Agronomía Medellín, 61(1), 4237-4247. [Online] Available: http://www.scielo.org.co/pdf/rfnam/v61n1/a01v61n1.pdf (August 24, 2019).

Barbosa, J. A., Ferreira, S. D., Salvalaggio, A. C., da Costa, N. V., \& de Moraes Echer, M. (2018). Alelopatia do extrato aquoso de Pachyrhizus erosus L. sobre Euphorbia heterophylla e Bidens pilosa. Pesquisa Agropecuária Tropical (Agricultural Research in the Tropics), 59-65. https://doi.org/10.1590/1983-40632018v4851117

Battistus, A. G., Bulegon, L. G., Vorpagel, J. A., Oliveira, T. L., \& Egewarth, V. A. (2011). 11670-Utilização de extrato de aveia preta (Avena stringosa) no desenvolvimento inicial de alface (Lactuca sativa) visando melhor qualidade das plantas. Cadernos de Agroecologia, 6(2). [Online] Available:

http://revistas.aba-agroecologia.org.br/index.php/cad/article/view/11670 (July 16, 2019).

Blum, U. (2011). Plant-plant allelopathic interactions. In Plant-Plant Allelopathic Interactions (pp. 1-7). Springer, Dordrecht. https://doi.org/10.1007/978-94-007-0683-5_1

Borella, J., \& Pastorini, L. H. (2009). Influência alelopática de Phytolacca dioica L. na germinação e crescimento inicial de tomate e picão-preto. Biotemas, 22(3), 67-75. https://doi.org/10.5007/2175-7925.2009v22n3p67

Bottega, S. P., Rech, J., Souza, L. C. F., Marques, R. F., Pedrotti, M. C., \& Torres, L. D. (2013) Desempenho agronômico do níger em função da época de semeadura para a Região Sul do Mato Grosso do Sul. Pesquisa Agropecuária Gaúcha, 19, 88-94. [Online] Available: http://www.fepagro.rs.gov.br/upload/1418841375_11.pdf (July 19, 2019).

Brasil. Ministério da Agricultura, Pecuária e Abastecimento. Secretaria de Defesa Agropecuária. (2009). Regras para análise de sementes. (1.ed.) MAPA/ACS, 398p. [Online] Available:

http://www.agricultura.gov.br/assuntos/insumos-agropecuarios/arquivos-publicacoes-insumos /2946_regras_analise_sementes.pdf (July 26, 2019) 
Campos, M. C. (2011). Modernização da agricultura, expansão da soja no Brasil e as transformações socioespaciais no Paraná. Revista Geografar, 6(1). https://doi.org/10.5380/geografar.v6i1.21808

Carneiro, M. A. C., Cordeiro, M. A. S., Assis, P. C. R., Moraes, E. S., Pereira, H. S., Paulino, H. B., \& de Souza, E. D. (2008). Produção de fitomassa de diferentes espécies de cobertura e suas alterações na atividade microbiana de solo de cerrado. Bragantia, 67(2), 455-462. https://doi.org/10.1590/S0006-87052008000200021

Carvalho, A. M. D., Bustamante, M. M. D. C., Almondes, Z. A. D. P., \& Figueiredo, C. C. D. (2014). Forms of phosphorus in an oxisol under different soil tillage systems and cover plants in rotation with maize. Revista Brasileira de Ciência do Solo, 38(3), 972-979. https://doi.org/10.1590/S0100-06832014000300029

Chon, S. U., Coutts, J. H., \& Nelson, C. J. (2000). Effects of light, growth media, and seedling orientation on bioassays of alfalfa autotoxicity. Agronomy Journal, 92(4), 715-720. https://doi.org/10.2134/agronj2000.924715x

Darolt, M. R. (2000). As dimensões da sustentabilidade: um estudo da agricultura orgânica na região metropolitana de Curitiba, Paraná (Doctoral Thesis, Universidade Federal do Paraná, Doutorado em Meio Ambiente e Desenvolvimento).

de Carvalho, W. P., de Carvalho, G. J., Abbade Neto, D. D. O., \& Teixeira, L. G. V. (2014). Alelopatia de extratos de adubos verdes sobre a germinação e crescimento inicial de alface. Embrapa Cerrados. Biosci. J., 30, 1-11. [Online] Available:

http://www.alice.cnptia.embrapa.br/alice/handle/doc/1008526 (September 02, 2019).

Ferreira, A. G., \& Borghetti, F. (2004). Germinação: do básico ao aplicado. Porto Alegre: Artmed, $323 \mathrm{p}$.

Ferreira, D. F. (2014). Sisvar: Um guia dos seus procedimentos de comparações múltiplas Bootstrap. Ciênc.Agrotec., 38(2), 109-112.

https://doi.org/10.1590/S1413-70542014000200001

Fontanétti, A., Carvalho, G. D., Morais, A. D., Almeida, K. D., \& Duarte, W. F. (2004). Adubação verde no controle de plantas invasoras nas culturas de alface-americana e de repolho. Ciência e Agrotecnologia, 28(5), 967-973.

https://doi.org/10.1590/S1413-70542004000500001

Formagio, A., Masetto, T., Baldivia, D., Vieira, M., \& Zarate, N. (2010). Potencial alelopático de cinco espécies da família Annonaceae. Revista brasileira de Biociências, 8(4). [Online] Available: http://www.ufrgs.br/seerbio/ojs/index.php/rbb/article/view/1485/975 (September 02, 2019)

Freitas, I. C. V., Silva, S. M., \& Melo, L. F. (2010). Efeito alelopático de extrato aquosos de resíduo de Pinus caribaea na germinação de soja, Agropecuária Técnica, 31(2), 88-89. https://doi.org/10.25066/agrotec.v31i2.4204

Getinet, A., \& Sharma, S. M. (1996). Niger (Guizotia abyssinica (L. f.) Cass.) promoting the 
conservation and use of underutilized and neglected crops. 5. Institute of Plant Genetics and Crop Plant Research, Gatersleben/International Plant Genetic Resources Institute, Rome, Italy. [Online] Available:

https://www.bioversityinternational.org/fileadmin/_migrated/uploads/tx_news/Niger_Guizot ia_abyssinica_L.f._Cass._136.pdf (September 01, 2019)

Gomes, A. A, Donato, A. F., Da Silva, W. J. C., \& Anese, S. (2017). Interferência de Guizotia abyssinica sobre germinação e crescimento de Ipomoea grandifolia. In: V Congresso Online - Agronomia. [Online] Available:

http://www.convibra.com.br/upload/paper/2017/86/2017_86_13601.pdf (August 29, 2019).

Gomes, A. A., Donato, A. F., \& Anese, S. (2019). Fitotoxicidade de espécies de Asteraceae cultivadas sobre gramíneas infestantes resistentes ao glifosato. Revista Brasileira de Agropecuária Sustentável, 9(1). https://doi.org/10.21206/rbas.v9i1.3044

Gordin, C. R. B., Marques, R. F., Masetto, T. E., Scalon, S. D. P. Q., \& de Souza, L. C. F. (2014). Temperaturas e disponibilidades hídricas do substrato na germinação de sementes de niger. Bioscience Journal, 30(3). [Online] Available:

http://www.seer.ufu.br/index.php/biosciencejournal/article/view/15146/14488 (July 15, 2019).

Hartman, G. L., West, E. D., \& Herman, T. K. (2011). Crops that feed the World 2. Soybean-worldwide production, use, and constraints caused by pathogens and pests. Food Security, 3(1), 5-17. https://doi.org/10.1007/s12571-010-0108-x

Hartmann, T. H., Kester, D. E., Davies, J. R. F. T., \& Geneve, R. (2001). Plant propagation: principles and practices. (7 ed.) New York: Prentice Hall, 880p.

Hirakuri, M. H., \& Lazzarotto, J. J. (2014). O agronegócio da soja nos contextos mundial e brasileiro. Embrapa Soja-Documentos (INFOTECA-E). [Online] Available: https://www.infoteca.cnptia.embrapa.br/bitstream/doc/990000/1/Oagronegociodasojanoscont extosmundialebrasileiro.pdf (September 01, 2019).

IAS - INTERNATIONAL ALLELOPATHY SOCIETY. (2015). Constitution and Bylaws. [Online] Available: http://allelopathy-society.osupytheas.fr/about/ (August 31, 2019).

Jabran, K., Mahajan, G., Sardana, V., \& Chauhan, B. S. (2015). Allelopathy for weed control in agricultural systems. Crop Protection, 72, 57-65.

https://doi.org/10.1016/j.cropro.2015.03.004

Javaid, A., \& Anjum, T. (2006). Control of Parthenium hysterophorus L., by aqueous extracts of allelopathic grasses. Pakistan Journal of Botany, 38(1), 139. [Online] Available: http://www.pakbs.org/pjbot/PDFs/38(1)/PJB38(1)139.pdf (August 30, 2019).

Kuo, W. L., Chen, C. C., Chang, P. H., Cheng, L. Y., Shien, B. J., \& Huang, Y. L. (2007). Flavonoids from Guizotia abyssinica. The Journal of Chinese Medicine, 18(3/4), 121-128. [Online] Available:

https://www.researchgate.net/profile/Chien-Chih_Chen5/publication/267843146_Flavonoids_ 
from_guizotia_abyssinica/links/575ab57108ae414b8e466aad/Flavonoids-from-guizotia-abyss inica.pdf (August 12, 2019).

Linares, J., Scholberg, J., Chase, C., McSorley, R., \& Fergusson, J. (2006). Integrative approaches for weed management in organic citrus orchards. HortScience, 41(4), 998A-998. https://doi.org/10.21273/HORTSCI.41.4.998A

Monquero, P. A., Amaral, L. R., Inácio, E. M., Brunhara, J. P., Binha, D. P., Silva, P. V., \& Silva, A. C. (2009). Efeito de adubos verdes na supressão de espécies de plantas daninhas. Planta Daninha, 27(1), 85-95. https://doi.org/10.1590/S0100-83582009000100012

Moreland, D. E., \& Novitzky, W. P. (1988). Interference by flavone and flavonols with chloroplast-mediated electron transport and phosphorylation. Phytochemistry, 27(11), 3359-3366. https://doi.org/10.1016/0031-9422(88)80732-5

Nishinari, K., Fang, Y., Guo, S., \& Phillips, G. O. (2014). Soy proteins: A review on composition, aggregation and emulsification. Food hydrocolloids, 39, 301-318. https://doi.org/10.1016/j.foodhyd.2014.01.013

Nunes, J. V. D., de Melo, D., Nóbrega, L. H. P., Loures, N. T. P., \& Sosa, D. E. F. (2014). Atividade alelopática de extratos de plantas de cobertura sobre soja, pepino e alface. Revista Caatinga, 27(1), 122-130. [Online] Available:

https://periodicos.ufersa.edu.br/index.php/caatinga/article/view/2990/pdf_94 (July 23, 2019).

Oliveira, S. C. C. (2009). Estudo alelopático de espécies do gênero Solanum do Distrito Federal. (Doctoral Thesis, Universidade Federal de São Carlos, São Carlos, São Paulo, Brasil. Doutorado em Ecologia e Recursos Naturais). [Online] Available: https://repositorio.ufscar.br/bitstream/handle/ufscar/1668/3012.pdf? sequence=1 (August 30, 2019).

Paszkowski, W. L., \& Kremer, R. J. (1988). Biological activity and tentative identification of flavonoid components in velvetleaf (Abutilon theophrasti Medik.) seed coats. Journal of Chemical Ecology, 14(7), 1573-1582. https://doi.org/10.1007/BF01012523

Rocha, B. G., Amaro, H. T., Porto, E., Gonçalves, C. C., David, A. M., \& Lopes, E. B. (2018). Sistema de semeadura cruzada na cultura da soja: avanços e perspectivas. Revista de Ciências Agrárias, 41(2), 91-100. https://doi.org/10.19084/RCA17260

Santos, V. H. M. (2012). Potencial alelopático de extratos e frações de Neea theifera Oerst. (Nyctaginaceae) sobre sementes e plântulas de Lactuca sativa. (Dissertation, Instituto de Biociências de Botucatu; Universidade Estadual Paulista, Botucatu, São Paulo, Brazil, Mestrado em Ciências Biológicas - Ecofisiologia). [Online] Available: http://hdl.handle.net/11449/92100 (August 28, 2019).

Sarin, R., Sharma, M., \& Khan, A. A. (2009). Studies on Guizotia abyssinica L. oil: biodiesel synthesis and process optimization. Bioresource Technology, 100(18), 4187-4192.

https://doi.org/10.1016/j.biortech.2009.03.072

Seegeler, C. J. P. (1983). Oil plants in Ethiopia: their taxonomy and agricultural significance. 


\section{Macrothink}

Addis Ababa, College of Agriculture and Wageningen, Agricultural University. 368p.

Silva, A. L. K., Silva, K. G., Paulert, R., Zonetti, P. C., \& Albrecht, L. P. (2015). Germinação e Crescimento Inicial de Plântulas de Euphorbia heterophylla L. e Glycine max L. Merril na Presença de Extratos Foliares de Salvia officinalis L. Revista em Agronegocio e Meio Ambiente, 8(2), 291-301. https://doi.org/10.17765/2176-9168.2015v8n2p291-301

Simonetti, A. P. M. M., Peres, D. M., Canzi, G. M., de Paula Souza, G. B., Effting, P. B., \& Moreira, C. R. (2019). Alelopatia da Crotalária ochroleuca sobre a Cultura da Soja. Revista Técnico-Científica, (17). [Online] Available:

http://creaprw16.crea-pr.org.br/revista/sistema/index.php/revista/article/view/536 (August 27, 2019)

Taiz, L., Zeiger, E., Møller, I. M., \& Murphy, A. (2017). Fisiologia e desenvolvimento vegetal. (6 ed.) Porto Alegre: Artmed Editora. 858 p.

Tur, C. M., Martinazzo, E. G., Aumonde, T. Z., \& Villela, F. A. (2012). Atividade alelopática de extratos aquosos de folhas de rabo-de-bugio sobre a germinação e o crescimento inicial de plântulas de alface. Revista brasileira de Biociências, 10(4), 521. [Online] Available: http://www.ufrgs.br/seerbio/ojs/index.php/rbb/article/view/2309/1163 (August 31, 2019).

Wilson, R. F. (2008). Soybean: market driven research needs. In Genetics and genomics of soybean (pp. 3-15). Springer, New York, NY. https://doi.org/10.1007/978-0-387-72299-3_1

\section{Copyright Disclaimer}

Copyright for this article is retained by the author(s), with first publication rights granted to the journal.

This is an open-access article distributed under the terms and conditions of the Creative Commons Attribution license (http://creativecommons.org/licenses/by/4.0/). 